May 2021

\title{
The Right to Read: The Fight to Desegregate Southern U.S. Public Libraries
}

Laura Wertz

San Jose State University, laurawertz90@gmail.com

Follow this and additional works at: https://scholarworks.sjsu.edu/ischoolsrj

Part of the Library and Information Science Commons

\section{Acknowledgements}

I would like to acknowledge the guidance of Dr. Donald Westbrook in developing this research topic. A lecturer in the School of Information MLIS program at San Jose State University.

\section{Recommended Citation}

Wertz, L. (2021). The Right to Read: The Fight to Desegregate Southern U.S. Public Libraries. School of Information Student Research Journal, 11(1). https://doi.org/10.31979/2575-2499.110106 Retrieved from https://scholarworks.sjsu.edu/ischoolsrj/vol11/iss1/6

This article is brought to you by the open access Journals at SJSU ScholarWorks. It has been accepted for inclusion in School of Information Student Research Journal by an authorized administrator of SJSU ScholarWorks. For more information, please contact scholarworks@sjsu.edu. 


\title{
The Right to Read: The Fight to Desegregate Southern U.S. Public Libraries
}

\author{
Abstract \\ The segregation of U.S. public libraries, particularly in the southern United States, is a shameful chapter in \\ library history. During the civil rights movement, the fight to desegregate was achieved through the \\ bravery and courage of peaceful protesters that staged protests in libraries across the south. The purpose \\ of this research paper is to examine how public libraries enforced segregation and some of the critical \\ protests that took place. The paper also explores the lack of recognition and awareness within the \\ librarianship profession and the general public and four recommendations for how public libraries can \\ begin to make amends.
}

\section{Keywords}

public libraries, segregation, protests, nonviolent, Civil Rights Movement, Brown v. Board of Education of Topeka, Martin Luther King Jr.

\section{Acknowledgements}

I would like to acknowledge the guidance of Dr. Donald Westbrook in developing this research topic. A lecturer in the School of Information MLIS program at San Jose State University.

\section{About Author}

Laura Wertz is a San Jose State University alumna who graduated with her master's in library and information science (MLIS) in May 2021. 
Public libraries have always stood as institutions that promote intellectual freedom, diversity, and acceptance. "A person's right to use a library should not be denied or abridged because of origin, age, background, or views" ("Appendix I American Library Association Library Bill of Rights," 2014, p. 771). However, a closer look at the past tells a vastly different story. Sadly, public libraries' complete history has been whitewashed for over six decades. While the American public knows the civil rights history of youth-led protests at lunch counters and on buses, fewer are aware of the fight that took place to desegregate public libraries. The bravery and courage on display during these protests are still not widely known today, both within the librarian profession and in the general public.

The segregation of public libraries, particularly in the southern United States, is a relatively unknown chapter of library history. Southern public libraries excluded Black patrons in a racist, bigoted, and humiliating manner. These actions went against everything libraries stand to uphold. However, like many institutions in America, public libraries became sites for ground-breaking activism and courage during the Civil Rights movement of the 1950s and 1960s. Graham (2002) found that public libraries were desired targets for peaceful protests, as they were prominent institutions most often located in the heart of southern cities. The fight for public libraries' desegregation in the southern United States quickly became a part of the broader equality journey. Peaceful protests served as an essential touchstone in creating change on the long road to desegregation in American society. This research paper examines how southern public libraries enforced segregation and some of the seminal protests in South Carolina, Mississippi, Louisiana, and Alabama. The paper also explores the historical events and individuals that served as inspiration for the protests, the lack of recognition of library segregation history within the profession of librarianship and the general public, and four recommendations for how public libraries can begin to make amends. Reconciliation must occur for public libraries to live up to their high standards and move forward in good faith with the Black community.

\section{Historical Overview}

\section{Brown vs. The Board of Education of Topeka and its Impact on Public Libraries}

On May 17, 1954, the Supreme Court of the United States ruled unanimously in Brown v. Board of Education of Topeka that racial segregation in public schools was a violation of the Fourteenth Amendment. The official decision applied only to public education, but it inferred that segregation was considered unconstitutional in other public settings, including public libraries. This ruling pushed open the door for peaceful protests in public libraries across the southern United States. Another Supreme Court case in 1955, dubbed Brown v. Board of Education II, declared that integration was to begin immediately. Nevertheless, no federal judicial ruling was strong enough to fully break the bonds of segregation. "While Brown appeared to make clear that separate public facilities such as libraries were inherently unequal and Brown II made clear that desegregation was to occur 'with all deliberate speed,' American society at least partially did not appear to desegregate libraries on their own initiative quickly" (Kuffner, 2008, p. 1261). It took relentless effort, bravery, 
and in many cases, the sacrifice of their safety and freedom by Black patrons to force public libraries to integrate. Civil disobedience was just the first step on that long road to equality.

\section{The Influence of Dr. Martin Luther King, Jr. on Nonviolent Protests in the Civil Rights Movement}

The beliefs and approach of Civil Rights leader Dr. Martin Luther King Jr. influenced the nonviolent manner of public library protests in the southern United States. King led the Civil Rights Movement with a pacifist philosophy of nonviolence from 1954 until his assassination in 1968. Cunningham (2018) found that Mahatma Gandhi's Hindu principles of Satyagraha (truth-force) and Ahimsa (love force or nonviolence) inspired King to create his six tenets of nonviolence:

1. Nonviolence is not passive nonresistance to evil; it is active nonviolent resistance to evil.

2. Nonviolence does not seek to defeat or humiliate the opponent, but to win his friendship and understanding.

3. Nonviolence is directed at the forces of evil rather than against persons who happen to be doing the evil.

4. The Nonviolent resister is willing to accept violence if necessary, but never to inflict it.

5. Nonviolence avoids not only external violence but also internal violence of spirit.

6. Nonviolence is based on the conviction that the universe is on the side of justice. (p. 340).

King believed that nonviolence was the only way to bring a clear vision of justice into the public consciousness. Activists put his principles of nonviolence, understanding, and love to good use in public library protests across the southern United States.

\section{Segregation in Southern Public Libraries}

Segregation in southern public libraries manifested in ways both subtle and obvious. If libraries were not restricting access to Black patrons altogether, they offered racially segregated services meant to humiliate and sternly discourage them from entering or returning to the library. For example, the Danville Public Library in Virginia created a vertical integration plan that provided limited services meant to frustrate and demean. After paying $\$ 2.50$ to fill out an application, Black patrons faced many absurd demands. "The new regulations required the applicant to list his place of birth, college degrees, type of books sought, the maximum number of books he would check out, two character references, and two business references" (Cresswell, 1996, p. 559). There were less apparent ways to uphold the status quo of segregation in public libraries. According to Knott (2015), White librarians and staff members would often sternly stare down Black patrons entering the building, while White patrons regularly requested that Black patrons not be allowed near them. With the painful memories of these experiences in mind and the anger over the insulting inadequacy of services and materials at colored libraries, the Black community across the south began to fight for their right to equality and access to 
information.

\section{Literature Review}

\section{The Greenville Eight}

On the morning of July 16, 1960, eight Black students-Dorris Wright, Hattie Smith Wright, Elaine Means, Willie Joe Wright, Benjamin Downs, Margaree Seawright Crosby, Joan Mattison Daniel, and future reverend and civil rights activist Jesse Jackson - walked into the whites-only Public Library in Greenville, South Carolina (Eberhart, 2017, pp. 34-35). Police quickly confronted the students, threatening to arrest them. They left before encountering library staff. The students had been counseled and supported in their endeavor by Reverend James S. Hall Jr., vice president of the South Carolina NAACP. Upon return to his church, Reverend Hall encouraged the students to return to the library. That afternoon, the eight students walked through the Greenville Public Library door again, determined to stay and face a probable arrest. Some of the students browsed the shelves, while others sat down at tables as a handful of White patrons began to file out of the building. Shortly after their arrest, Reverend Hall arrived with Black attorney Donald J. Sampson, and the court released each of them on a $\$ 30$ bond.

On July $28^{\text {th }}$, Sampson filed a lawsuit with the U.S. District Court for the Western District of South Carolina, hoping that the Greenville Library system would desegregate. In response, the mayor of Greenville closed both the White and Black branches of the library on September $2^{\text {nd }}$ rather than face a court order of integration. This response was common practice for public libraries of the era when faced with pressure to integrate. However, public pressure from the community regarding their displeasure with the closures forced the city to reopen both Greenville libraries just twelve days later. A statement from the mayor read, "The city libraries will be operated for the benefit of any citizen having a legitimate need for the libraries and their facilities. They will not be used for demonstrations, purposeless assembly, or propaganda purposes" (Weigand \& Weigand, 2018, p. 80 ). Though this statement reads more as a condemnation of the peaceful protest rather than a celebration of social justice, the outcome was still considered a victory for the Black community of Greenville. Although the Greenville Library was not the first in South Carolina to integrate, it was the first to do so in direct response to a protest. The eight students had their charges dropped, and the Greenville Eight took their place amongst other civil rights heroes of the era. 


\section{Figure 1}

Booking of the Greenville Eight

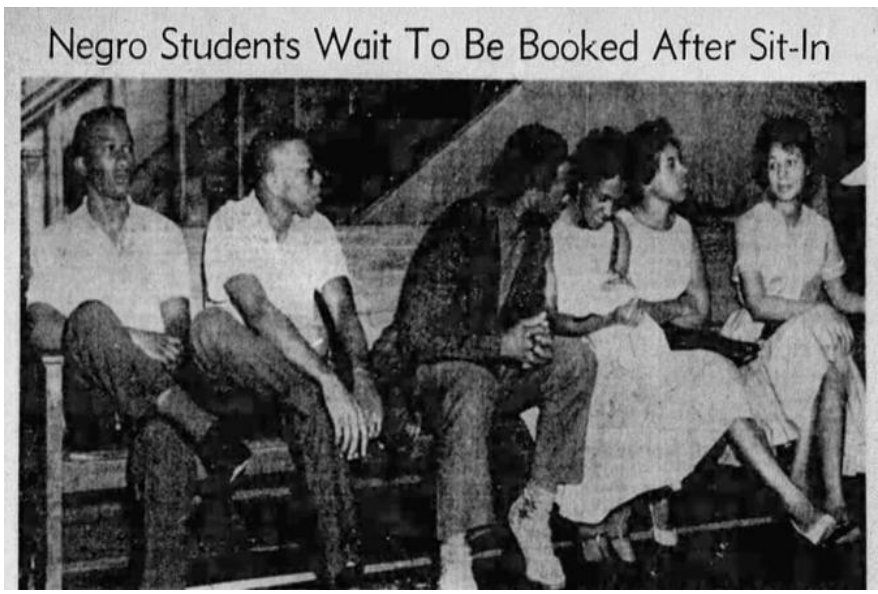

Note: Greenville Eight students waiting to be booked following their sit-in at the Greenville Public Library on July 16, 1960, in Greensville, South Carolina. From "The Greenville Eight: The Sit-In That Integrated the Greenville Library," by G. Eberhart, 2017, American Libraries, 48(6), p. 35 (https://www.jstor.org/stable/26380947). Copyright 2017 by the American Library Association. Reprinted with permission.

\section{The Tougaloo Nine}

On the morning of March 27, 1961, nine NAACP-member students from the historically Black college of Tougaloo University-Joseph Jackson Jr., Albert Lassiter, Alfred Cook, Ethel Sawyer, Geraldine Edwards, Evelyn Pierce, Janice Jackson, James Bradford, and Meredith Anding Jr. - walked into the whites-only Public Library in Jackson, Mississippi (Wiegand,2017, p. 32). The White staff member behind the circulation desk began berating the students, and the Library Director strongly suggested that the students visit the colored branch of the library. Six police officers arrived shortly after, as the studentswere quietly reading and browsing through the card catalog. The officers told them to leave, but none of the students moved. They were promptly arrested and held on a $\$ 500$ bond.

As night fell on Jackson, Mississippi, the students began to fear for their lives. Jackson Jr. started to rehearse what he would say if the Klu Klux Klan came for them, fearing he would have to plead for his life for the sake of his wife and two children (Wiegand, 2017, 34). Police drove the students to the courthouse a few days later. Hundreds of supporters greeted and cheered the now dubbed "Tougaloo Nine" upon their arrival. In response to this show of support, the police confronted the crowd with nightsticks and attack dogs.

On March $29^{\text {th }}$, the students were taken to court and found guilty of breach of peace. The court fined each student $\$ 100$, and their 30-day sentences were suspended on the condition that they would no longer engage in any protests (Weigand \& Weigand, 2018). The NAACP responded by filing a class-action lawsuit on January 12, 1962. Five months later, a federal judge ordered the Jackson Public Library to desegregate, a direct result of the Tougaloo Nine's bravery and 
determination.

\section{Figure 2}

The Tougaloo Nine

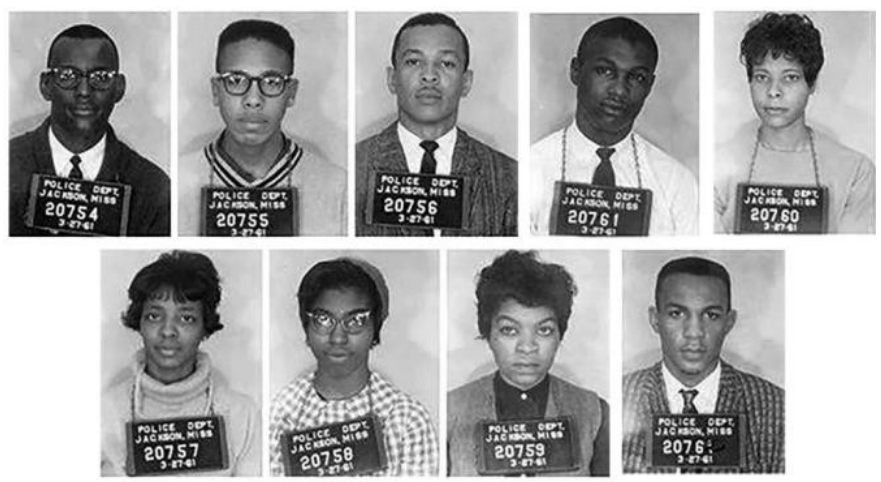

Note: The Tougaloo Nine: Joseph Jackson Jr., Geraldine Edwards, James "Sammy" Bradford, Evelyn Pierce, Albert Lassiter, Ethel Sawyer, Meredith Anding Jr., Janice Jackson \& Alfred Cook. From "Desegregating Libraries in the American South: Forgotten Heroes in Civil Rights History," by W. Weigand, 2017, American Libraries, 48(6), p. 32 (https://www.jstor.org/stable/26380946). Copyright 2017 by the American Library Association. Reprinted with permission.

\section{Anniston Alabama}

On September 15, 1963, two young Black ministers, Reverend Quintus Reynolds and Reverend William McClain, notified the whites- only Anniston Public Library and city officials that they would be entering the premises intending to obtain library cards (Cresswell, 1996, p. 561). The AnnistonPublic Library did not want the attention brought by law enforcement. Despite efforts to keep this integration attempt quiet, a hostile White crowd was waiting outside the library for Reynolds and McClain to arrive. As the two men approachedthe library's entryway, they were physically attacked and accosted with fists, sticks, and chains. Reverend Reynolds and Reverend McClain were unable to escape in their car. The two men were able to flag down a Black driver after fleeing on foot,who took them to the hospital. The events of Anniston, Alabama, illustrate a hallmark of many protests during the Civil Rights movement, a violent response topeaceful action.

That night, the mayor of Anniston, the Chairman of the Library Board, and the Human Relations Council Chairman visited Reverend Reynolds and Reverend McClain in the hospital, promising positive action. The following day, city officials personally escorted the two men back to the Anniston Public Library to procure their library cards. This event was the beginning of integration in Anniston as more Black residents began to register for library cards. Reverend Reynolds and Reverend McClain's beating is regarded as the most brutal moment in the library integration movement. However, it received little press as it sadly occurred on the same day as the tragic $16^{\text {th }}$ Street Baptist Church Bombing that killed four young Black girls in Birmingham, Alabama.

\section{Ouachita Parish Libraries}

The desegregation efforts of public libraries in Louisiana benefited from the Congress of Racial Equality organization (CORE). After the passage of the Civil 
Rights Act of 1964, CORE was determined to "test"Jim Crow laws in various public institutions in rural Louisiana, including public libraries. A week later, on July 9, 1964, at approximately 2:30 p.m., twelve Black high school students from Monroe, Louisiana, entered the Anna Meyer Branch Library, part of the Ouachita Parish Library System. Dorothy Higgins, Jimmy Andrews, and Etta Faye Carter browsed the shelves before sitting down at a table together to read (Weigand \& Weigand, 2018). Bennie Roy Brass used the card catalog to find a book before approaching the circulation desk. He kindly stated his intention to register for a library card so he could check out the book. After being told multiple times that he could not have a library card and should go to the colored branch of the library, Brass returned to his table and continued to read. Students engaging in these protests knew full well that the librarians and staff members would deny their requests. The goal was always to assert their rights keep a level head.

Police arrived after this encounter and asked the students to leave. Minutes later, the police chief appeared and insisted the Black teenagers go; five did. Law enforcement arrested the seven students who stayed for disturbing the peace and trespassing. Weigand \& Weigand (2018) describe the heated interrogation that began once the students were in police custody about their CORE association. Police demanded to know who got the students into CORE and who told them to come to the library. Officers even accused them of being Communists. The students were arrested, transported to juvenile detention cages, and held for three days before being released to their parents on $\$ 200$ bail.

Protesters were not discouraged and refused to give up after one unsuccessful attempt. CORE tests of the three White branches of the Ouachita Parish Public Libraries continued with similar protests on July $14^{\text {th }}$ and July $20^{\text {th }}$. Black students, some as young as thirteen years of age, quietly and peacefully entered the libraries. When they were denied service and refused to leave without registering for library cards, police arrested the students for disturbing the peace and trespassing on library property. Archival notes from CORE paperwork underscore the influence of Dr. King's nonviolent principles, as well as the organized manner of these public library protests. Youthful testers were encouraged to know their part and stay composed. Weigand \& Weigand (2018) paint a detailed picture of how thoroughly CORE counseled students beforehand:

Throughout, testers were instructed to "conduct yourselves quietly." When arrested, testers should "go limp" if experiencing force, only answer questions on "vital statistics," and at the police station request one phone call each. In jail, they were to choose a spokesperson and to set up a daily schedule that included exercise, prayers, singing (not at "late hours," however), and "quiet times." (p. 271)

On July $28^{\text {th }}$, three students who participated in the CORE protests filed a lawsuit in the Monroe division of the federal district court, stating that the Ouachita Parish Public Libraries' segregation was unconstitutional. City officials presented a plan to relocate and build a new library branch in opposition to this lawsuit. A yearlong fight between civil rights activists and the city of Monroe ended with city officials relenting. The Ouachita Parish Public Libraries integrated in 1965. The Louisiana protests underscore the determination of protesters and activists. 
Students engaged in a long and protracted fight for justice. These undertakings' legal and social complexities were not a discouragement but a stepping-stone to equality.

\section{A Visual Illustration: Albany, Georgia, 1962}

No matter how effective the written word is in setting the scene or conveying the emotions of public library protests during the Civil Rights Movement, nothing can compare to seeing one with your own eyes. The 1962 silent news clip from WALB Television in Albany, Georgia, gives a first-hand glimpse of public library protests, and perhaps just as telling, the reaction of White patrons and library staff. In the summer of 1962, Black students in Albany, Georgia, began testing Brown v. Board of Education's validity by entering different public institutions. The archival news clip starts with two young Black girls approaching the Albany Carnegie Library's circulation desk. After speaking with two White library staff members, they retrieve books from the stacks and sit down quietly at a table to read. Seeing them, a White patron seated at an adjacent table gathers her belongings and leaves. The film quickly cuts to the Black girls exiting the building. In the second half of the news clip, four Black students walk up the library's steps. They speak to someone inside the library who refuses to open the door more than a few inches, and the students turn around and walk away. Rather than integrate the facilities, the Albany City Commission closed the library in 1962. In 1963, at local citizens' request, the library reopened with no patron seating (WALB news film clip, 1962). Still fighting against full integration like the Danville Public Library in Virginia, these partial integration services were begrudgingly handed over to frustrate and ultimately dissuade Black patrons from coming to the Albany Carnegie Library.

As evident from this archival video, many of the protesters were relatively young, a historical characteristic of activism and peaceful protest that continues to this day. Standing up to injustice recognizes no age limits. The students took matters into their own hands and lived up to Dr. King's peaceful and nonviolent philosophy with composure and courage wise beyond their years.

\section{Methodology and Sources}

The methodologies employed in this research paper were secondary data analysis / archival studies. The King Library Database at San Jose State Universityand broader Google searches retrieved numerous secondary sources in monographsand scholarly journal articles that helped build the overview of this paper. Academic Search Complete, Library and Information Science Source, and the Civil Rights Digital Database were the primary databases used in the research process, each of them retrieving sufficient resources. Sources cover a broad range of the southern United States to present the similarities and differences of protests within different states. One primary source was used to create this paper: a silent video of a 1962 news report on a library protest in Albany, Georgia. This artifact provided an excellent first-hand visual account of what public library protests looked like during the Civil Rights Movement. Historical background research was conducted on the Supreme Court case of Brown v. The Board of Education of Topeka (1954) and Brown II (1955). Understanding these cases' impact is key to understanding how politics, history, and racial culture converge. Furthermore, historical analysis of the 
correlation between the nonviolent principles of Civil Rights Leader Dr. Martin Luther King Jr. and the peaceful manner of the public library protests illustrates the Civil Rights Movement's broad reach across the full spectrum of public institutions.

\section{Discussion}

The history of segregation in southern U.S. public libraries is a shameful chapter in American library history. Not only because of the racism and humiliation inflicted upon Black patrons but because the librarian profession has done very little to reconcile this history. The rhetoric does not line up with reality. None of the tenets established in the Library Bill of Rights applied to Black patrons. The Black Caucus of the American Library Association (ALA) was established in 1970 to advocate for Black patrons' and librarians' rights (The Black Caucus of the American Library Association, 2020). However, despite this governing body's long existence within the profession, the organization was not granted a professional affiliation with the ALA until 1992. Furthermore, it was not until June of 2018 that the ALA passed a resolution to honor African Americans who fought library segregation (American Library Association, 2018, p.10). Beyond this symbolic apology and a promise to review internal procedures to ensure equity, diversity, and inclusion, the ALA has not announced any concrete national policy implementations. In each of the cases examined above, police arrested the participants for disturbing the peace or trespassing. The ALA must reconcile why Black patrons asserting their right to equal access to information was a public disturbance.

The first step in reconciling this dark past is for public libraries to acknowledge the injustices. In July of 2010, four members of the "Greenville Eight" came together 50 years after their protest at the Greenville Public Library to reflect (Weigand, 2017, p. 18). Members were disappointed to learn that the library has no public marker to commemorate the Greenville Eight's bravery. Moreover, in researching the other public libraries discussed in this paper as they stand today, it was saddening to find that none of the libraries mentioned these protests on their respective "about us" web pages or historical timelines. Formerly segregated libraries where protests took place should have visible historical markers on site, and information concerning this period of history should be easily viewable on library websites. Public apologies on behalf of the libraries to the protest participants is a necessary starting point. The acknowledgment must occur at the local level to move forward in good faith.

The second step is to educate the general public about library segregation history. Southern public libraries must go beyond merely acknowledging the past injustices, and the Black community must have a seat at the table in this process. According to Simon (2016), patrons must be invited in on their terms, with generosity, humility, and recognition of their experiences. Public libraries should collaborate with Black community leaders to educate the general public. Library programming, such as historical exhibitions and presentations on the history of library segregation and the fight for desegregation, is just the beginning of the community outreach process. The heroes who participated in desegregating public libraries are getting older, but their first-hand experiences are crucial to the education process. Library administration officials should be reaching out to these individuals to participate in talkbacks and offer insight on future proceedings. 
Doing so will begin to acknowledge the reality of their experiences and include them in the solution.

The third step is acknowledging the racial blind spots in the profession of librarianship and working to correct them. Libraries have historically been Whitemajority institutions. At last count, the ALA reports that only 4.4\% of ALA member librarians identify as Black or African American (ALA Office for Research and Statistics, 2017, p. 2). This is an unacceptable ratio more than six decades on from library desegregation. If the Black community is not represented in public libraries, so continues a gap in public trust. Whether the profession realizes it or not, segregation continues to shape how Black patrons viewlibraries today. The Black Caucus of the ALA provides leadership for the recruitment and professional development of Black librarians. The E.J. Josey Scholarship offers Black students financial assistance to pursue a graduate-level library and information science degree. (The Black Caucus of the American Library Association, 2020). Scholarships of this nature must continue to decrease the racial disparity gap in the profession of librarianship.

The fourth step is for public libraries to commit to programs, policies, and procedures that benefit Black patrons rather than enabling the barriers to access that began in the days of library segregation. Excluding the Black community through unaddressed racial biases in public libraries' institutional structure is the grandchild of segregation. The Government Alliance on Race and Equity (GARE) has partnered with many public libraries throughout the United States in the last decade to increase library access for communities of color and work toward racial equity.

The GARE Theory of Change (2018) recommends six strategies and components that public libraries can utilize to create systems of change:

Normalize

- Cultivate high-level investment

- Establish internal Change Teams

Organize

- Build capacity among staff and stakeholders

- Partner with other institutions and communities

Operationalize

- Use Racial Equity Assessment Tools

- Create a Racial Equity Action Plan (Local and Regional Government Alliance on Race \& Equity, 2018, p. 13)

This framework is crucial to public libraries seeking to confront racism and unaddressed prejudices in their programs, policies, and procedures. There are three stages and six steps in the GARE Equity Framework. Normalizing racial equity cultivates a high-level of investment through collaboration with local city governments. Change is more likely to occur when it becomes an institutional priority. Therefore, a shared value must be developed between the library and local civic leaders. Public libraries should also establish internal Change Teams to examine the history of library segregation and the current library policies and 
practices that shape conditions for the Black community. Organization in the GARE Equity Framework builds a capacity among library staffand stakeholders and forms partnerships with local racial justice leaders. This collaboration will begin to remove barriers to access for Black patrons and examine racial bias in the recruiting and hiring of Black librarians and staff members. The operationalizing process begins with a Racial Equity Assessment (REA). The REA seeks to eliminate racial inequities, identifies clear goals and measurable outcomes, engages the community in the decision-making process, explores who will be impacted by new decisions, and develops mechanisms to implement these changes (Local and Regional Government Alliance on Race \& Equity, 2018, p. 30). The assessment is a steppingstone to deepening the internal dialogue between public libraries and the Black community. The culmination of the aforementioned steps and stages prepares public libraries to create a Racial Equity Plan. The Racial Equity Plan (REP) outlines the desired results, indicators, outcomes, specificactions, performance measures, timeline, and accountability (Local and Regional Government Alliance on Race \& Equity, 2018, pp. 35-36). Similar to a Library's Strategic Plan, the REP provides a concrete structure and linear timeline for publiclibraries to embed programs, policies, and procedures in the long-term.

The tools and mechanisms created by the Local and Regional Government Alliance on Race \& Equity have been put to good use by numerous public libraries over the years. In 2016, the Seattle Public Library (SPL) identified Race and Social Justice as a core component of their Strategic Plan by using the GARE Equity Framework. SPL conducted a thorough analysis of its bookmobile routes. A crossreference of racial and demographic data showed that the bookmobile was not serving low-income children of color as adequately as White children (Local and Regional Government Alliance on Race \& Equity, 2018, p. 17). SPL revised its map to increase stops in low-income minority neighborhoods in response. Moreover, the Saint Paul Public Library used the Racial Equity Assessment to investigate implicit racial bias in issuing guest passes for patrons who provided proof of out-of-state residence to use library computers. The library staff was often discrete in issuing guest passes. Extensive survey results showed that patrons who appeared to be minorities were denied a guest pass more often than those who appeared to be White (Local and Regional Government Alliance on Race \& Equity, 2018 , p. 32). The survey results led to eliminating the policy and the library issuing guest passes to anyone upon request.

Finally, although there is scholarly research addressing the history of segregation in southern public libraries, gaps in the literature still exist. The protests discussed in this paper are cited most frequently in articles exploring the history of library segregation. However, like many hidden figures throughout history, there are numerous other cases of protests throughout the south and across the United States that received no news coverage. No matter how small in size, every public library protest that stood up to the injustice of library segregation contributed to the journey of equality. Examinations of more library protests would be valuable for future study and vital in bringing awareness to this crucial chapter in American history.

\section{Conclusion}


Bolstered by the defining legislative moment of Brown v. Board of Education of Topeka, Brown II, and Martin Luther King Jr.'s nonviolent philosophy, the peaceful protests examined in this paper serve as a sobering reminder that everyone has the right to equal access to information, and everyone is welcome in libraries. Segregation in southern public libraries is only a tiny reflection of racism during the civil rights movement. However, if we try to erase these narratives, we are engaged in a grave injustice: an injustice against the brave participants of these protests, the history of libraries, and the librarian profession.

Despite the progress made regarding equality and equal access to library services for Black patrons, the cycle of clouding the full history of public libraries in the United States continues today. The majority of the librarian profession and the general public are unaware that the stain of segregation extended to public libraries, a disappointing truth exacerbated by the lack of acknowledgment, education, and diversity in the profession of librarianship, all of which must be corrected. Public libraries can begin to move forward equitably by collaborating with racial justice leaders and the Black community to create programs, policies, and procedures that benefit Black patrons. Libraries stand today as safe spaces of freedom. No one should forget the sad reality that this was not always the case; it should be a permanent part of the public consciousness so that the institution of libraries may continue to live up to its highest ideals.

\section{References}

ALA Office for Research and Statistics (2017). 2017 ALA demographic study. [PDF]. http://www.ala.org/tools/sites/ala.org.tools/files/content/Draft $\% 20$ of $\% 20$ Member\%20Demographics\%20Survey\%2001-11-2017.pdf

Appendix I American Library Association Library Bill of Rights. (2014). Library Trends, 62(4), 771-771. https://doi.org/10.1353/lib.2014.0014

Black Caucus of the American Library Association. (2020, December 11). About $B C A L A$. Black Caucus American Library Association. https://www.bcala.org/about-bcala

Cresswell, S. (1996). The last days of Jim Crow in southern libraries. Libraries \& Culture, 31(3/4), 557-573. www.jstor.org/stable/25548457.

Cunningham, R. M. (2018). The march from Selma to Montgomery and the nonviolent movement in analysis. Psychological Perspectives, 61(3), 331343. https://doi.org/10.1080/00332925.2018.1495512

Eberhart, G. (2017). The Greenville Eight: The sit-in that integrated the Greenville Library. American Libraries, 48(6), 34-35. https://www.jstor.org/stable/26380947

Knott, C. (2015). Not free, Not for all: Public libraries in the age of Jim Crow. University of Massachusetts Press. https://doi.org/10.2307/j.ctt1hd1917

Kuffner, M. R. (2008). From public schools to public libraries: Examining the impact of Brown V. Board of Education on the desegregation of public Libraries. Alabama Law Review, 59(4), 1247-1275. https://heinonline.org/HOL/P?h=hein.journals/bamalr59\&i=1260

Local and Regional Government Alliance on Race \& Equity. (2018). Advancing 
racial equity in public libraries: Case studies from the field [PDF]. https://www.racialequityalliance.org/wpcontent/uploads/2018/04/GARE LibrariesReport v8 DigitalScroll_WithH ע perlinks.pdf

Patterson, T. (2002). A right to read: Segregation and civil rights in Alabama's public libraries, 1900-1965. University of Alabama Press. https://ebookcentral.proquest.com/lib/sjsu/reader.action?docID $=438178$

Resolution to Honor Those Who Fought Segregation. (2018). American Libraries, 49(9/10/2018), 10.

Simon, N. (2016). The Art of Relevance. Museum 2.0.

WALB. (1962). News film clip of African American students turned away from the public library in Albany, Georgia, [Video file], http://crdl.usg.edu/do:ugabma walb_walb00033

Wiegand, W. (2017). “Any ideas?": The American Library Association and the desegregation of public libraries in the American south. Libraries: Culture, History, and Society, 1(1), 1-22 https://doi.org/10.5325/libraries.1.1.0001

Wiegand, W. (2017). Desegregating libraries in the American south: Forgotten heroes in civil rights history. American Libraries, 48(6), 32-37. https://www.jstor.org/stable/26380946

Weigand, W. A., \& Weigand, S. A. (2018). The desegregation of public libraries in the Jim Crow south: Civil rights and local activism: LSU Press. 